\title{
RADICALIZATION IN THE TEACHING RELIGION AND ITS RELATIONS WITH CRIMINAL ACTS OF TERRORISM
}

\author{
Hoiruddin Hasibuan $^{1}$, Sudarsono ${ }^{2}$, I Nyoman Nurjaya ${ }^{3}$, Bambang Sugiri ${ }^{4}$ \\ ${ }^{1}$ Doctoral of Legal Science Program, Faculty of Law, Brawijaya University \\ ${ }^{2}$ Law Faculty, Brawijaya University \\ ${ }^{3}$ Law Faculty, Brawijaya University \\ ${ }^{4}$ Law Faculty, Brawijaya University \\ Email: hoiruddinhasibuan@gmail.com
}

Submitted: 2017-04-07 | Accepted: 2017-07-12

\begin{abstract}
The criminal act of terrorism is a crime against humanity, human civilization and constitute a serious threat to the integrity and sovereignty of a nation. In fact, terrorism can be a threat to a state security and sovereignty as well as world peace.

It is argued that one of the main causes of criminal acts of terrorism is radicalization. Thus, this paper seeks to analyze the casual link between radicalization and terrorism. This paper determines to what extent does the radicalization affected the criminal acts of terrorism. This research uses a juridical normative method by analyzing legal instruments relating to terrorism and seeks to analyze the reason behind the provided rules.

This paper submitted that while radicalization affected terrorism, de-radicalization is urgent in responding to terrorism. This paper also proposes how de-radicalization works in preventing terrorism.
\end{abstract}

Keywords: Terrorism, Religious Radicalization, Indonesia

\section{INTRODUCTION}

The common thread between radicalization and terrorism became increasingly apparent after the WTC tragedy. The world brought in the global fight against terrorism led by the United States. The September 11 attack that claimed by American as the terror act by $\mathrm{Al}$ Qaeda militants carried out by changing the political map of the world and the international perception of the terminology or definitions of terrorism and radicalism. The President of the United States at the time, George W. Bush called a global war DOI: http://dx.doi.org/10.21776/ub.blj.2017.004.02.02 against terrorism around the world. Post the terror attacks, President Bush declared that the country is in a state of war with terrorists and promised to made laws in order to "fight something far beyond conventional criminality" that are specific to the fight against crimes that are far different from conventional crime ${ }^{1}$. Additional reaction to the terrorist attacks on 11 September 2001 also came from the UN Security Council (acting on Chapter VII of the UN Charter)

\footnotetext{
${ }^{1}$ Whittaker, D, J, The promised legislation emerged in the form of Act for Uniting and Strengthening America by Providing Appropriate Tools Required to Intercept and Obstruct Terrorism (The USA PATRIOT Act), 193.
} 
by publishing a resolution requesting states to improve the prevention and control of terrorism, including preventing their safe place (save havens) for those who finance, plan, and assist terrorism ${ }^{2}$.

From the perspective of criminology as explained, the reaction of the state against violation of the law must be hung on the causes of the violation of the law (criminal etiology). Therefore, only by understanding the root causes that gave rise to the phenomenon of terrorism, states can react appropriately to the treatment efforts ${ }^{3}$. Further, as the author's deepening analysis to unravel the common thread between terrorism and radicalism in the literature, the author found the factors that affect the occurrence of terrorism, which are, among others: lack of social welfare ${ }^{4}$, widespread poverty $^{5}$, education ${ }^{6}$, demography (the structure and dynamics of the population as a factor criminogenic ), the weakness of state's power range, the failure of democracy, lack of access to political

2 UNSC Res. 1368, 12 Sept. 2001, UN Doc. S/Res/1368 (2001) and UNSC Res 1373, 28 Sept. 2001, UN Doc/Res/1373 (2001).

3 Wulandari, Widati "'Public Emergency" sebagai alasan mengeyampingkan kewajiban negara dibawah ICCPR : Reaksi Terhadap Terorisme', (2013), I, 1, Jurnal Hukum Internasional, 27.

4 Burgoon,B, 'On Welfare and Terror : Social Welfare Policies and Political - Economic Roots of Terroris', (2006) 502 The Journal of Conflict Resolution, 176- 203.

${ }^{5}$ Gurr, T, R, "Economic Factors", in Richardson, L, ed, The Roots of Terrorism, (New York : Routledge, 2006), 85 - 99.

${ }^{6}$ Krueger, A, B, and Maleckova, J, 'Education, Poverty and Terrorism : Is there a Causal Connection?', (2003) 174 Journal of Economic Perpectives, 119 - 144. policy, as well as radicalism or fundamentalism. ${ }^{7}$

Indeed, until now, experts still disagree about how dominant a factor in the emergence of terrorism. But one thing which has been agreed upon is that terrorism tends to arise when countries and communities experiencing a radical social-political transition. $^{8}$

The authors has made above that according to the literature, one of the causes of terrorism is fundamentalism, or in other terms called radicalism. The impact of September 11, 2001 tragedy then gives a negative stigma to one of the great religion that exist in this world. Whether coincidence or not, due to the WTC attackers who are Muslim, it then causes this religion to also be given a negative stigma, at least by most western countries as the religion of terrorists ${ }^{9}$.

Yet is it true that a specific extraordinary crime (in this case, the acts of terrorism), which cannot be justified by any reason, is fully monopolized by fundamentalism or radicalism teachings of a particular religion? The author, in that regard as well, departing from the study of the etiology of crime, will examine briefly the problems that they had been caused by the emergence of terrorism on the teachings

\footnotetext{
7 Juergensmeyer, M, "Religion as a Cause of Terrorism", in Richardson,(2006) above n.5, 133 143

${ }^{8}$ Wulandari, Widati (2013) above n.3 28.

9 Trump, D, Islam dan Teroris, (02 July 2016), <http://www.detik.com>
} 
ofvarious religions. Because only with this approach, I believe we can assess and sort that religious radicalism is not necessarily synonymous with terrorism even though both have a relationship of mutual influence.

\section{LEGAL MATERIALS METHODS}

The type of this research is a normative legal research, which uses a constitutional approach in the form of a study juridical normative study which then attempted to pull the legal principles in the formulation of norms that will become a reference / input in the preparation of the legislation draft on Combating Criminal Acts of Terrorism, by ascertaining the philosophical, juridical, and sociological facts through a literature study that examines through the study materials in the form of legislation and the results of the research, the results of the assessment, as well as other references as the primary data and secondary data.

While the methods that being used in the writing of this study is a normative legal writing $^{10}$, that is a way of writing based on an analysis of some of the principles of law

\footnotetext{
${ }^{10}$ This normative legal research is a daily activity for a scholar of law study, indeed, a normative research on law is only capable to be conducted by a scholar on law study, as an individu that educated to understand and comprehend law study. As suggested by C.F.G Sunaryati Hartono, Penelitian Hukum di Indonesia pada Akhir Abad ke-20, (Bandung: Penerbit Alumni, cetakan ke-2, 2006), 139.
}

and legal theory and legislation that appropriate and are associated with the problems in this study. This normative legal research is a procedure and how scientific research is conducted to find out the truth based on scientific legal logic from normative terms ${ }^{11}$.

In addition to a normative legal research methods, to complete the proof of the accuracy of the data and for the sake of de-radicalization program, the authors also used a qualitative approach. According to Creswell, qualitative research is research that produce and process the nature of descriptive data, such as the transcription of interviews, field notes, questionnaires, pictures, photographs, videotapes, and others. In the dissertation, it was done an indepth interviews with participants who were former terrorism convicts to collect relevant and valid data on the implementation of deradicalization conducted by Badan Nasional Penanggulangan Terrorisme (BNPT) or the National Counter-Terrorism Agency in tackling terrorism in Indonesia, so the next step that be done in-depth analysis and improvement of the implementation of deradicalization of the National Counterterrorism Agency (BNPT).

\footnotetext{
${ }^{11}$ Johnny Ibrahim, Teori dan Metodologi Penelitian Hukum Normatif, (Malang: Bayu Media Publishing, 2006), 57.
} 


\section{RESULTS AND DISCUSSIONS}

1. What is Radicalism

and

\section{Fundamentalism?}

Radicalism is a view that wants to do a fundamental change in accordance with the interpretation of espoused ideology or social reality. Radical changes can be done not only in a peaceful persuasive way but also with physical violence or symbolic violence. At the end, radicalism tends to be synonymous with violence even to the suicide for the meaningfulness of life which he believed ${ }^{12}$.

As if judging from linguistic, radical comes from the word radix or radical that means $\operatorname{root}^{13}$. So it can be said that a person could be a radical in any caseradically because could be interpreted as rooted, very deep, or appreciate the particular teachings or doctrines. However, radical is not only in the carrying out of the context of a particular religious teachings or doctrines, but can also be on other things outside of the teachings or doctrines such as the genre of arts, music, or painting. The important thing here is someone who has radical symptom is almost the same or very similar to those with addiction. As someone who is addicted to things like cigarettes, gaming, and many more will do anything to satisfy the desire of

\footnotetext{
${ }^{12}$ Gelose, Petrus Reinhard, Deradikalisasi Terorisme : Humanis, Soul Approach, dan Menyentuh Akar Rumput, (Jakarta : Yayasan Pengembangan Kajian Ilmu Kepolisian, 2009), 38.

13 Bill, Lillian, Black Law English Dictionary, (Michigan Press : UCLA 1988), 367

the addiction, a radical also will do anything to run something he believes ${ }^{14}$.

Johan Galtung tried to conceptualize the kind of radicalism into three forms, namely cultural radicalism, structural radicalism, and direct radicalism. Cultural radicalism is a radicalism that legitimizes the structural radicalism and direct radicalism. Direct radicalism (violence-asaction) itself is interpreted as a radicalism that looks directly in the form of events or actions, making it easy to identify the kind of radicalism. While the structural radicalism (violence-as-structure) is defined as the systematic exploitation of radicalism that is shaped with a mechanism that block the formation of consciousness, as well as inhibiting the presence of institutions that could oppose the exploitation and oppression. $^{15}$

The structural radicalism which posed by Johan Galtung was basically provides an understanding, that radicalism can be done by anyone and under any circumstances, whether the state, communities, specific groups, or even individuals can become perpetrators of radicalism. However, the country still seen by John Galtung as having great potential to eliminate the right of its citizens to realize themselves in the political field.

\footnotetext{
14 Toshiro, Yuma, 'Addict and Radix, Radical : Are Same?', (2003) Jurnal Psikologi, 62.

15 Galtung, Johan, 'Violence, Peace and Peace Research', (1969), 63 Journal of Peace Research, 170-171.
} 


\section{What is Terrorism?}

In a various acts of violence which are categorized as the act of terrorism, both in domestic and foreign, it appears that what happened actually is ordinary crimes. The perpetrators (whatever his motivation) is basically guilty of commonly recognized as murder or death threats, violence and threats of violence, assault, bombing or the use of explosives, destruction, or even a bank robbery or just plain theft. What exactly makes ordinary crimes be different and thus be qualified in the category of a criminal act of terrorism? ${ }^{16}$.

To answer this question can be referenced to how international crime formulated. In the statute of the International Criminal Court $^{17}$, crimes of genocide, war crimes, and crimes against humanity are also includedas murder or violence that committed with the specific purpose of destruction of part or all members of a particular group (racial, national, ethnic, or religious). On war crimes, the ordinary similar crimesshould be proved that has been done in terms of their situations of armed conflict (international or internal) and constitutes a serious violation of humanitarian law set forth in the Geneva Conventions of 1949. Meanwhile, to qualify as crimes against humanity, a number of other elements must be proven. The first is

\footnotetext{
${ }^{16}$ Wulandari, Widati, (2013), above n. 3, 22.

${ }^{17}$ International Criminal Court (ICC) was established by Rome Statute 1998
}

that the culprit is a state or a stateorganizations; second, that the act was directed against a civilian population; and third, the act is part of an attack whose characteristic is widespread and systematic. In other words, the evil nature of acts qualified as an international crime is special and can not be equated with evil nature of ordinary crimes ${ }^{18}$. It also said that the crime is considered the most serious crimes of concern to the international community as a whole $^{19}$. That's also why the offense is set up specifically as an international crime in the Statute of the International Criminal Court.

Likewise with terrorism, the crime of terrorism is basically referring to the usual crime acts committed in a particular context and led to the belief that the state reactions must also be specific. It is indicated on the international instruments to criminalize a wide form of terrorism since $1970 \mathrm{~s}^{20}$, such

18 Schabas, W, Introduction to the International Criminal Court, $2^{\text {nd }}$, (Cambridge : Cambridge, University Press, 2004), 36 - 66.

19 Triffterer, O, Commentary on the Rome Statute of The International Criminal Court, $2^{\text {nd }}$, (Beck oHG : Verlag C.H., 2004), 16.

${ }^{20}$ Tokyo Convention on Offences and Certain Others Acts Committed on Board Aircraft (1963), Hague Convention for the Suppression of Unlawful Seizure of Aircraft (1970), Convention for the Suppression of Unlawful Acts Against the Safety of Civil Aviation (1971), Protocol for the Suppression of Unlawful Act of Violence at Airports Serving International Civil Aviation (1988), Convention of the Prevention and Punishment of Crimes Against Internationally Protect Persons (1973), International Convention Against the Taking of Hostages (1979), Convention on the Physical Protection on Nuclear Material (1980), Convention for the Suppression of Unlawful Acts Against the Safety of Maritime 
as aircraft hijacking, kidnapping - hostage of people - certain people, and so on. The acts are allegedly specific(political) objectives.

The background of certain motivations, as well as defines the action or an act of terrorism, also distinguishes it from ordinary crime. In general, terrorism is defined as "the use of violence or threat of violence againstcivilian population, to achieve a political goal" or "any actions to threaten or intimidate the civilian population to influence the policy of the government" or "the act of creating and exploiting the fear of civilians through violence or threats of violence to achieve political change $" 21$. Thus, it seems clear that their "political motivation" is the most important element is the context or background to do theterrorismaction. This motivation in the last analysis is aimed to overthrow the legitimate government or simply force the government to change or drive the direction of political policy.

Such understanding is in line with the text of Article 2 Draft Text of the Convention International Terrorism which

Navigation (1988), Protocol for the Suppression of Unlawful Act Against the Safety of Fixed Platforms Located on the Continental Shelf (1988), Convention on the Marking Plastic Explosive for the Purpose of Identification (1991), European Convention on the Suppression of Terrorism (1977), Council Framework Decision of 13 June 2002 on Combating Terrorism, Intern American Convention Against Terrorism (2002), The Arab Convention for the Suppression of Terrorism (1998), Convention of the Organization of the Islamic Conference on Combating International Terrorism (1999).

${ }^{21}$ Goodwin, J, 'A Theory of Categorical Terrorism', (2006) 844 Social Forces, 2027 - 2046 was prepared by the Counter Terrorism Committee $^{22}$. In the design of such provision, terrorism is defined as a criminal offense committed by a person (any person commits an offense), by any means, unlawfully (unlawfully) and deliberately (intentionally) and said, 'inter alia' death or serious bodily injury to any person ... when the purpose of the conduct, by it's nature or context, is to intimidate a population, or compel a Government or an international organization to do or abstain from doing any act. '

The approach can also be found in the U.S. Code. Terrorism in this U.S. Code is defined as "premeditated, politically motivated violence, perpetrated against non - combatant targets by sub - national groups or clandestine agents, usually intended to influence an audience." ${ }^{23}$ Implicitly stated that the main victims of terrorism acts (whose background was political) is the civil society (non - combatants) and directed, usually (meaning not necessarily) to influence a group of people (not necessarily state / government). There is no mention here of any separatism actions that often use terror as a way to pressure the government.

Slightly different is the understanding of the definition of terrorism in Indonesia. In the Government Regulation in Lieu of Law No. 1 year 2002 on the Eradication of Terrorism which has been set into an act

\footnotetext{
${ }^{22}$ Counter Terrorism Committee was wstablished by UN SC Resolution 1373 (2001)

${ }^{23}$ U.S. Code, title 22, sec 265 f (d)
} 
through Law No. 15 year 2003, terrorism is defined as an act "... that deliberately use violence or threat of violence, creating an atmosphere of terror or fear of the widespread or cause the victim that is massive, by robbing the independence or loss of life or property of others, or cause damage or destruction of vital strategic objects or environment or public facilities or international facilities ". Terrorism provisions in the above legislation is also extended to any actionsthat include planning and other preparatory actions undertaken in the context of terrorism.

What is noteworthy here is the exclusion of interest or political motivation or will to influence government's policy as the elements of crime. Within the provisions of Article 5 decree above, it mentiones that "The criminal acts of terrorism are stipulated in the Government Regulation in Lieu of Laws which is excluded from political crimes, crimes related to political crimes, criminal acts with political motives, and criminal offenses with political objectives, which inhibit the process of extradition. "It appears that the makers of the legislation explicitly intend to separate political nuanced crimes (subversion, insurrection, or separatism) from criminal acts of terrorism by removing the element of political motivation behind the terrorism actionson the formulation of the offense of terrorism. ${ }^{24}$

\footnotetext{
${ }^{24}$ Wulandari, Widati, 2013, above n. 3, 24.
}

It appears also that the release of the political motivation of the formulation of the offense of terrorism was motivated by pragmatic interests, namely that the perpetrator (suspect, defendant, or convict) of terrorism remains can be requested or extradited to another country and not obstructed general prohibition in the (legal) extradition, which is not to hand over fugitives of political criminal suspect ${ }^{25}$. Other legal consequence is that the Prosecution does not have to prove the element of intent to achieve the political or ideological objectives. It does not need to be revealed in court.

The actions of terrorism which have occurred in Indonesia, usually have a purpose or a particular political background or at least done as a form of resistance (protest) against government's policies or to force the government to do something. Even according Djelantik in this context, it is implicitly distinguishes terrorism based on the presence or absence of political motivation. He stated that political terrorism is a phenomenon that is an extension of political opposition, which is a product of a long process of delegitimation against public order or the existing regime ${ }^{26}$.

\footnotetext{
${ }^{25}$ See Article 3 Model Treaty on Extradition (Adopted by General Assembly resolution) 45/116, subsequently amended by General Assembly resolution 52/88). Also see Article 5 Paragraph (1) Law No. 01 Year 1979 on Extradition.

${ }^{26}$ Djelantik, S, “Terorisme : Tinjuan Psiko - Politis, Peran Media, Kemiskinan, dan Keamanan Nasional, (Jakarta : Yayasan Pustaka Obor Indonesia, 2011), 4 - 6.; See also Djelantik, S,
} 
Based on this, we could conclude that there are a number of elements that distinguish terrorism from conventional criminal offense. The most important distinguishing element is that (1) the effect or intention to put fear in the community (indiscriminately); (2) through violence or threat of violence (manifested in a variety of form of crime; and (3) performed to achieve certain political goals (influence government's policy in public order).

Such a conclusion also appears when we look at the historical development of the terrorismactions. From this point of view, it can be distinguished some waves as well as the type or motive of terrorist movements in the world. According to Rapoport, there are four waves of terror with a different motive, namely: anarchism, national liberation, social revolution, and religious transcendence ${ }^{27}$. From this perspective it is clear that a terrorist act is aimed at the ruling government, with or without the intention to overthrow or replace it. Political motivation, thus, even if confirmed in Indonesian National Laws that it is not an element of the crime of terrorism and cannot be separated from the terrorist actions. The chosen way might be very cruel, inhuman,

Terrorism in Indonesia : The Emergence of West Javanese Terrorist, East - West Centre Paper No. 22, 2006, available on http://www.eastwestcenter.org/fileadmin/stored/pdf s/IGSCwp022.pdf

${ }_{27}$ Rapoport, D, in Weinberg, L \& Eubank, W, 'An End to the Fourth Wave of Terrorism ?', (2010) Vol. 33 No. 7 Studies in Conflict \& Terrorism, 594 -602 . and clearly against the state laws, but often with specific purposes. In this case,the purposes of terror is as a mean to achieve political or ideological objectives from another viewpoint that is believed by many actors.

\section{Teachings of Religions Has Potential} -to be Used- as the Tool of Radicalization

The author has to sort out and spoke about fundamentalism or radicalism and terrorism clearly. There is a visible red thread on the relationship between one to another. This was confirmed at least by the analysis and scientific argumentation that religious doctrine directly or indirectly, have contributed to terrorism through the misused doctrine or teaching, thus creating radicalism or fundamentalism by Rapoport and Juergensmeyer summed up as one of the causes of terrorism.

Further still associated with these opinions, Afadlal explains,theoretically, how the shift from radicalism or fundamentalism to terrorism were initially moved from the concept of fanaticism. Expressing fanaticism and radicalism or fundamentalism can appear in many forms. Yet, it is generally proportional to the reaction or the attitude of the opposing group. The action and reaction between the two opposing groups may be different, but in general both is approaching a similar degree and pattern. Violence will be 
countered with violence and one of its forms can be tangible to terrorism. ${ }^{28}$

Tito Karnavian explained the relationship between Religion, Violence, Terrorism, and Radicalism in detail in the riot in Poso around the years 2000s ago. It is undeniable that the riots were triggered from fanaticism of two major religions, Islam and Christianity, which is prolonged even continues until the writing of this journal. Poso riot became one of the dark history of radicalism in this nation and easy to resolve even through the 20 December 2001 Malino Peace Declaration, which was pioneered by Mr. Jusuf Kalla and the religion leaders of Islam and Christianity. ${ }^{29}$

Tito Karnavian analyzed that the initial cause of the riot was actually just because of misunderstanding between youths/teenagers who happened to come from a different religion. ${ }^{30} \mathrm{~A}$ few years later, even to the completion of this article, operation Tinombala 2 has been officially given the title of terrorists to Santoso and his flock. It is apparent here that there is a common thread between radicalism or fundamentalism with terrorism.

Observing the Poso case as national concern, the author found that all religions have the potential to be radicalized by some paragraphs in religious scripture, which can

\footnotetext{
28 Afadlal, Afadlal et all, Islam dan Radikalisme di Indonesia, (Jakarta : LIPPI Press, 2005), 9.

${ }^{29}$ Karnavian, Tito, Indonesia Top Secret Membongkar Konflik Poso, (Jakarta : Gramedia Pustaka Utama), 375.

${ }^{30}$ Ibid. 52.
}

be interpreted not in the real purpose of the paragraphs when those holy verses were revealed. Paragraphs on Jihad in Al-Quran, among others, are "O Prophet, do strive (against) infidels and Hypocrites, and be firm against them. Their place is Hell. And it is the worst place to return" (At - Tawbah: 44), "Do not follow infidels, jihad against them with Al-Quran by a great Jihad "(Al Furqan: 52). There are more than 30 verses in Al-Quran about Jihad that frequently being misused by unscrupulous person to radicalize those with low levels of faith. ${ }^{31}$ While in $\mathrm{Al}$ - Kitab, there was discovered some verses that can be used or misused to radicalize a Christian, among others, "They crush them with the sword everything in the city, both men and women, both young and old ..." (Joshua 10: 28), "Do not suppose that I came to bring peace on the earth; I come not to bring peace, but to bring a sword" (Matthew 10: 34), and "ye shall chase your enemies, and they shall fall before you by the sword, five of you will chase a hundred, and a hundred of you will chase ten thousand and all thine enemies shall fall before you by the sword" (Leviticus 26: 7$8) .^{32}$

The facts demonstrate that although there is a link between terrorism and radicalism, but religious radicalism is

\footnotetext{
${ }^{31}$ Mustafa, Ali, "30 Ayat Al - Quran Dilarang Baca Mengandung Seruan Jihad”, (13 September 2016), <http://www.kompasiana.com>

${ }^{32}$ Ayat - ayat radikal dalam Al-Kitab, (13 September 2016), <http://www.wordpress.com>
} 
actually no more than a contributing factor to a variety of basic issues that going complex. There is no single deal about things that become the factors into the cause of the birth of radical attitudes and behavior, but what is clear is that radicalism can not be separated by acts of violence such as terrorism. Even the understanding of radical by many countries including Indonesia is considered as the root that causes terrorism, as well as the emergence of the Islamic State of Iraq and Sham (ISIS) that carries religious motive in the form of a khilafah, and later became an organization that similar to states via the proclamation of Islamic State (Daulah Islamiyah) to lift Abu Bakr al - Baghdadi as caliph at the end of June 2014.

Therefore, in efforts to deal with them, it can not be viewed only from one side, but need a comprehensive approach. It means that counter-terrorism that sourced from radicalism or fundamentalism is not enough just through the repressive-actions measures alone, but on the other hand need to be completed thoroughly and fairly to the root causes that give rise to the phenomenon of terrorism.

\section{CONCLUSIONS AND SUGGESTIONS}

Freedom of religion is fully guaranteed in the Constitution of the Republic of Indonesia and the International Human Rights. Even the ICCPR (International
Covenant on Civil and Political Rights 1966). However, in case of a state of national emergencies (public emergency) a state is allowed to put aside Human Rights but is limited by Article 4 paragraph (1): "in times of public emergency which threaten the life of the nation and the existence of which is Officially proclaimed, the States Party to the preset Covenant may take measures derogating from their obligation under the present Covenant by the extent strictly required by the exigencies of the situation, provided that such measures are not inconsistent with reviews their other obligations under international law and do not involve; discrimination solely on the ground of race, color, sex, language, religion or social origin." Even further in paragraph 2 the above provisions confirmed that the restriction can not be done to the rights that qualified as a non-derogable rights: the right to life, freedom from torture, freedom from enslavement, the right not to be tried by a court that is retroactive, and the right to pertain freedom of religion.

All religion's members have the potential to be fanatic and could further be radical or fundamental. However, a person does not automatically mean radical terrorists. Because radicalism only one motive causes of terrorism.

Religion (Agama) comes from the word A - not, and Gama - corrupted. Therefore, essentially, religions should have the power to fix order, improve a corrupted 
human being and bring him back to his nature as the creation of God that nourishes the earth. The state's obligation to protect all its people and prevent religion for not being used as a tool to radicalize its followers so that potential to perform terrorism.

For example the Religious Rehabilitation Group (RRG) held in Singapore, it is good for religious leaders who had participated in this deradicalization programs to be included in a training or certification, so these religious leaders are ready to caress the prisoners of terrorism that still inherent radicalism in their ideology.

Empowering communities to participate in combating criminal acts of terrorism such as religious education to promote the true and moderate value, as well as, moral education based on Pancasila in schools.

Given the latent danger of terrorism and the threat of the high intensity, then the introduction of the budget allocation for the deradicalization program needs to be considered and granted, unlike today. Because with an adequate budget, the quality and quantity of human resources that responsible for de-radicalization program could be improved, and the infrastructure also will be able to support this program.

\section{REFERENCES}

Journal Articles
Burgoon,B, 'On Welfare and Terror : Social Welfare Policies and Political Economic Roots of Terrorism', (2006), 502 The Journal of Conflict Resolution, 176 - 203.

Goodwin, J, "A Theory of Categorical Terrorism", (2006), 844 Social Forces, 2027 - 2046

Krueger, A, B, and Maleckova, J, 'Education, Poverty and Terrorism : Is there a Causal Connection', (2003), 174 Journal of Economic Perpectives, $119-144$.

Rapoport, D, in Weinberg, L \& Eubank, W, 'An End to the Fourth Wave of Terrorism ?', (2010) 337 Studies in Conflict \& Terrorism, 594-602.

Toshiro, Yuma, 'Addict and Radix, Radical : Are Same ?', (2003) Jurnal Psikologi , 62

Wulandari, Widati, 'Public Emergency Sebagai Alasan Mengeyampingkan Kewajiban Negara Dibawah Iccpr : Reaksi Terhadap Terorisme', (2013) 1

1 Jurnal Hukum Internasional, 27.

\section{Books}

Afadlal, Afadlal et all, Islam dan Radikalisme di Indonesia, (Jakarta : LIPPI Press, 2005).

Bill, Lillian, Black Law English Dictionary, (Michigan Press : UCLA, 1988) 
Djelantik, S, Terorisme : Tinjuan Psiko Politis, Peran Media, Kemiskinan, dan Keamanan Nasional, (Jakarta : Yayasan Pustaka Obor Indonesia, 2011)

Galtung, Johan, Violence, Peace and Peace Research, (Oslo:Journal of Peace Research, Vol 6 No.3, 1969)

Gelose, Petrus Reinhard, Deradikalisasi Terorisme : Humanis, Soul Approach, dan Menyentuh Akar Rumput, (Jakarta : Yayasan Pengembangan Kajian Ilmu Kepolisian, 2009)

Johnny Ibrahim, Teori dan Metodologi Penelitian Hukum Normatif, (Bayu Media Publishing, Malang, 2006)

Karnavian, Tito, Indonesia Top Secret Membongkar Konflik Poso, (Jakarta : Gramedia Pustaka Utama).

Schabas, $\mathrm{W}$, Introduction to the International Criminal Court, $2^{\text {nd }}$, (Cambridge : Cambridge, University Press, 2004)

Sunaryati Hartono, Penelitian Hukum di Indonesia pada Akhir Abad ke-20, (Bandung: Penerbit Alumni, cetakan ke-2, 2006)

Triffterer, O, Commentary on the Rome Statute of The International Criminal Court, $2^{\text {nd' }}$, (Beck oHG : Verlag C.H., 2004).

Gurr, T, R, "Economic Factors", in Richardson, L, ed, The Roots of
Terrorism, (New York : Routledge, 2006).

\section{Conventions}

Convention for the Suppression of Unlawful Acts Against the Safety of Civil Aviation (1971)

Convention of the Prevention and Punishment of Crimes Against Internationally Protect Persons (1973)

International Convention Against the Taking of Hostages (1979)

Convention on the Physical Protection on Nuclear Material (1980)

Convention for the Suppression of Unlawful Acts Against the Safety of Maritime Navigation (1988)

Convention on the Marking Plastic Explosive for the Purpose of Identification (1991)

European Convention on the Suppression of Terrorism (1977)

Council Framework Decision of 13 June 2002 on Combating Terrorism

Intern American Convention Against Terrorism (2002)

Convention of the Organization of the Islamic Conference on Combating International Terrorism (1999)

Hague Convention for the Suppression of Unlawful Seizure of Aircraft (1970) 
Protocol for the Suppression of Unlawful Act of Violence at Airports Serving International Civil Aviation (1988)

Protocol for the Suppression of Unlawful Act Against the Safety of Fixed Platforms Located on the Continental Shelf (1988)

The Arab Convention for the Suppression of Terrorism (1998)

Tokyo Convention on Offences and Certain Others Acts Committed on Board Aircraft (1963)

\section{United Nations Documents}

Whittaker, D, J, Pg..193, The promised legislation emerged in the form of $A c t$ for Uniting and Strengthening America by Providing Appropriate Tools Required to Intercept and Obstruct Terrorism (The USA
PATRIOT Act) UNSC Res. 1368, 12 Sept. 2001, UN Doc. S/Res/1368 (2001) and UNSC Res 1373, 28 Sept. 2001, UN Doc/Res/1373 (2001).

\section{Internet}

Ayat - ayat radikal dalam Al-Kitab, (13 September 2013), $<$ http://www.wordpress.com>

Djelantik, S, 'Terrorism in Indonesia: The Emergence of West Javanese Terrorist', (03 September 2015), $<$ http://www. eastwestcenter.org >

Mustafa, Ali, '30 Ayat Al - Quran Dilarang Baca Mengandung Seruan Jihad', (13 September 2013), $<$ http://www.kompasiana.com> Trump, D, Islam dan Teroris, (02 July 2016), <http://www.detik.com> 
